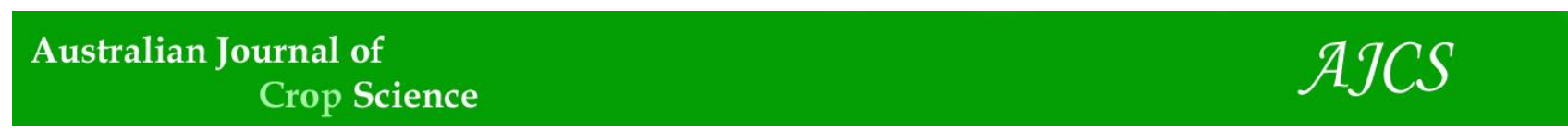

AJCS 11(10):1268-1276 (2017)

ISSN:1835-2707

doi: 10.21475/ajcs.17.11.10.pne520

\title{
Beetroot production using Calotropis procera as green manure in the Brazilian Northeast semiarid
}

\author{
Manoel Galdino dos Santos ${ }^{1}$, Ênio Gomes Flôr Souza ${ }^{1,2}$, Antonia Francilene Alves da Silva ${ }^{3}$, Michele \\ Barboza $^{3}$, Enielson Bezerra Soares ${ }^{1}$, Hamurábi Anízio Lins ${ }^{1}$, Aurélio Paes Barros Júnior ${ }^{1 *}$, Lindomar \\ Maria da Silveira ${ }^{1}$, Francisco Bezerra Neto ${ }^{1}$
}

\author{
${ }^{1}$ Departament of Crop Science, Universidade Federal Rural do Semi-Árido (UFERSA), Av. Francisco Mota, 572, \\ Costa e Silva, CEP 59625-900, Mossoró, RN, Brazil \\ ${ }^{2}$ Instituto Federal de Alagoas (IFAL), Av. Sergipe, s/n, Xingó, CEP 57460-000, Piranhas, AL, Brazil \\ ${ }^{3}$ Unidade Acadêmica de Serra Talhada (UAST), Universidade Federal Rural de Pernambuco (UFRPE), Av. \\ Gregório Ferraz Nogueira, s/n, José Tomé de Souza Ramos, CEP 56909-535, Serra Talhada, PE, Brazil
}

*Corresponding author: aurelio.barros@ufersa.edu.br

\begin{abstract}
The use of green manures in vegetable crop production systems has increased, but there is still a lack of information about the correct handling of the species for better use by culture. Two field experiments were conducted in Serra Talhada in the semiarid of Pernambuco state, Brazil, to evaluate the effects of amounts of biomass and times of Calotropis procera incorporation into the soil in the agronomic performance of the beetroot 'Early Wonder' in two growing seasons (fall and spring-summer). The experimental design was a randomized block in three replications. The treatments were arranged in a $4 \mathrm{x} 4$ factorial scheme, with the first factor corresponding to the quantities of $C$. procera biomass $\left(5.4,8.8,12.2\right.$, and $15.6 \mathrm{Mg} \mathrm{ha}^{-1}$ on a dry basis) and the second to the times of incorporation into the soil $(0,10,20$, and 30 days before sowing of beetroot). The following characteristics were assessed in the beetroot: plant height, number of leaves per plant, root diameter, total productivity, commercial productivity, and dry mass of roots. The amount of $C$. procera as well as the time of incorporation and growing season directly influenced the agronomic performance of beetroot. Regardless of the assessed agronomic characteristics, increasing amounts, and decreasing the time of incorporation proportionally influenced the performance of beetroot. The best agronomic performance of the beetroot was obtained by fertilization with $15.6 \mathrm{Mg} \mathrm{ha}^{-1}$ of $C$. procera. The ideal time of incorporation of green manure coincided with the date of the sowing of beetroot. The cultivation in the fall season resulted in higher total and commercial productivity of beetroots fertilized with $C$. procera.
\end{abstract}

Keywords: Beta vulgaris L.; Calotropis procera (Ait.) R. Br.; green fertilizer; organic fertilization; soil and climate conditions. Abbreviations: DBS - days before sowing.

\section{Introduction}

The beetroot (Beta vulgaris L.) is a vegetable crop belonging to the Quenopodiaceae family, widely cultivated throughout Brazil (Filgueira, 2008). To obtain the maximum yield of the beetroot, the proper management of the factors that influence the growth and development of culture, such as its water and nutritional needs, is necessary (Barlog et al., 2013). In nutritional terms, beetroot is considered a demanding crop in a balanced fertilizer. According to Granjeiro et al. (2007), the nutrients accumulated by beetroot, in decreasing order, are $(\mathrm{N})$, potassium $(\mathrm{K})$, magnesium $(\mathrm{Mg})$, calcium $(\mathrm{Ca})$, and phosphorus (P).

Green manures contain important sources of plant nutrients, and their use can reduce the amount of manure applied in organic production systems and contribute directly to the replacement of nutrient reserves in the soil (Linhares et al., 2009; Linhares et al., 2012; Sediyama et al., 2014). The use of green manure in the soil has promoted varied effects on the agronomic performance of the crops depending on the species used, the management of the biomass, the planting season of the crop, length of time on the ground, local climatic conditions, and the interaction between these factors
(Alcântara et al., 2000). The spontaneous species of the Caatinga biome, hairy Merremia aegyptia L., Calotropis procera (Ait.) R. Br., and Senna uniflora L., have contributed so positive when used as green manure in organic systems of production of lettuce (Góes et al., 2011), coriander (Linhares et al., 2012), arugula (Souza et al., 2016), beetroot (Batista et al., 2016; Silva et al., 2011), carrot (Bezerra Neto et al., 2014; Oliveira et al., 2011), and radish (Batista et al., 2013).

The $C$. procera belongs to the Apocynaceae family, with wide geographical distribution, particularly in arid and semiarid conditions (Souto et al., 2008; Carvalho Júnior et al., 2010). This species remains lush and green throughout the year, forming a shrub that is fast growing and exhibits vigorous regrowth, with a production capacity of approximately $700 \mathrm{~kg}$ of dry matter per hectare within 60 days after cutting (Andrade et al., 2008). The content of nitrogen, phosphorus, and corresponding potassium is 17.4, 4.4 , and $23.5 \mathrm{~g} \mathrm{~kg}^{-1}$ dry weight, respectively, and their $\mathrm{C} / \mathrm{N}$ ratio is $25 / 1$, which favors the mineralization process of organic matter. Some studies have shown the potential of this type to be used as green manure with various crops, such as 
carrot (Silva et al., 2013), radish (Silva et al., 2017), lettuce (Souza et al., 2017), and arugula (Souza et al., 2016). Cultivation of beetroot with $C$. procera provided total and commercial root productivity of $18.74 \mathrm{Mg} \mathrm{ha}^{-1}$ and $16.33 \mathrm{Mg}$ $\mathrm{ha}^{-1}$, respectively (Batista et al., 2016).

In general, vegetable crops require large amounts of nutrients in a short time, considering their nutritional needs. The amount as well as the time of biomass incorporation directly influences the availability of nutrients for crops (Bezerra Neto et al., 2011; Oliveira et al., 2011). Biomass decomposition is controlled by soil microorganisms, environmental conditions, and the chemical composition of the material (Xu and Hirata, 2005; Batista et al., 2013, 2016). If there is a high rate of mineralization of the nutrients of the biomass used as green manure outside the period of high nutrient demand of the crop, leaching losses can occur, resulting in no absorption of nutrients in the stage of higher nutritional requirements (Crews and People, 2005).

In addition to fertilization, local climatic conditions are one of many pre-harvest factors affecting the yield of vegetables. In Brazil, there are few studies that demonstrate the productive potential of beetroot grown under different meteorological conditions. The sertão of the state of Pernambuco presents two climatic conditions, in which, in the spring-summer, the average air temperatures (above 25 ${ }^{\circ} \mathrm{C}$ ) and the photoperiod (above 12h) are higher than in autumn-winter, which can affect the productive response of beetroot and the mineralization of green manure.

The objective of this study was to evaluate the effects of different amounts of $C$. procera biomass and ground incorporation times in two cropping seasons (fall and springsummer) in the agronomic performance of beetroot.

\section{Results}

\section{Joint analysis of variance}

There was interaction between growing seasons and amounts of $C$. procera biomass, as well as between seasons and incorporation times of green manure for plant height, number of leaves per plant, and root diameter. Interaction between the three factors (growing seasons, amounts of biomass, and incorporation times) occurred for total and commercial productivity and dry mass of roots.

\section{Plant height, number of leaves per plant, and diameter of the beetroots}

The plant height and the number of leaves per plant were higher in the fall season compared to the spring-summer cultivation, regardless of the amount of biomass and the incorporation time (Tables 1 and 2). The diameter of the beetroots planted in the spring-summer was smaller than to the fall in all amounts of biomass, except dose $15.6 \mathrm{Mg} \mathrm{ha}^{-1}$. In both growing seasons, the height of beetroot plants increased with increasing amounts of $C$. procera biomass, reaching maximum values of 26.56 (fall) and $24.11 \mathrm{~cm}$ (spring-summer), when the fertilizing consisted of 14.65 and 15.6 $\mathrm{Mg} \mathrm{ha}{ }^{-1}$, respectively (Fig. 1A). In contrast, linear reductions were observed in the plant height between the lowest and the highest ground incorporation time for the green manure, with differences of $3.73 \mathrm{~cm}$ in the fall and 1.92 $\mathrm{cm}$ in the spring-summer (Fig. 1B).

The number of leaves per beetroot plant increased linearly with increasing amounts of $C$. procera incorporated into the soil, reaching maximum values of 11.80 (fall) and 9.88 (spring-summer) of leaves per plant with the amount of 15.6 $\mathrm{Mg} \mathrm{ha}^{-1}$ of C. procera (Fig. 2A). Partitioning the interaction by times of incorporation within growing seasons, it was observed that the number of leaves per plant was reduced with the increase in the time that the green manure stayed in the ground, independent of the planting period of the crop (Fig. 2B).

The root diameter increased linearly with increasing amounts of green manure (Fig. 3A). Each ton of $C$. procera added to the soil caused increase of 0.06 (fall) and 0.26 (spring-summer) in the root diameter. Similar to what occurred for the height and number of leaves per plant, the diameter of beetroot was reduced when it was fertilized later in relation to the sowing, with larger differences in springsummer cultivation (Fig. 3B).

\section{Total productivity of beetroots}

The increased amount of $C$. procera biomass increased the total productivity of beetroots, with maximum values of $46.48 \mathrm{Mg} \mathrm{ha}^{-1}$ (fall) and $40.99 \mathrm{Mg} \mathrm{ha}^{-1}$ (spring-summer) with the amounts of 14.08 and $15.6 \mathrm{Mg} \mathrm{ha}^{-1}$ of green manure, respectively, associated with 0 days before sowing (DBS) (Fig. 4AB)

Maximum values of total productivity were obtained when the green manuring was held on the beetroot planting day (Fig. 4CD). This time of incorporation along with the amount of $15.6 \mathrm{Mg} \mathrm{ha}^{-1}$ of $C$. procera yielded the highest values of total root productivity, both in fall cropping $\left(46.56 \mathrm{Mg} \mathrm{ha}^{-1}\right)$ and in spring-summer cultivation (41.48 $\left.\mathrm{Mg} \mathrm{ha}^{-1}\right)$.

\section{Commercial productivity of beetroots}

In the fall, it was estimated the commercial productivity of beetroots of $35.53 \mathrm{Mg} \mathrm{ha}^{-1}$ using $14.23 \mathrm{Mg} \mathrm{ha}^{-1}$ of $C$. procera added to the soil 10 days before planting of the crop (Fig. $5 \mathrm{~A})$. In the second period, the amount of $15.6 \mathrm{Mg} \mathrm{ha}^{-1}$ of green manure at 0 DBS resulted in commercial productivity of $33.78 \mathrm{Mg} \mathrm{ha}^{-1}$, followed by the treatments at $10(29.52 \mathrm{Mg}$ $\mathrm{ha}^{-1}$ ), 20 (28.54 $\mathrm{Mg} \mathrm{ha}^{-1}$ ), and 30 (26.96 $\mathrm{Mg} \mathrm{ha}^{-1}$ ) DBS (Fig. $5 \mathrm{~B})$.

Regarding the interaction partition of ground incorporation times within the amounts of $C$. procera, there were no adjustments of the regression equations for the first growing season (fall) in the amounts of $5.4 \mathrm{Mg} \mathrm{ha}^{-1}, 12.2 \mathrm{Mg} \mathrm{ha}^{-1}$, and $15.6 \mathrm{Mg} \mathrm{ha}^{-1}$, but the average productivity of these amounts were $25.86 \mathrm{Mg} \mathrm{ha}^{-1}, 32.23 \mathrm{Mg} \mathrm{ha}^{-1}$, and $34.22 \mathrm{Mg} \mathrm{ha}^{-1}$, respectively (Fig. 5C). For the spring-summer, the estimated incorporation time of 1.26 days associated with $15.6 \mathrm{Mg} \mathrm{ha}^{-1}$ of $C$. procera yielded the maximum value of $33.64 \mathrm{Mg} \mathrm{ha}^{-1}$ of commercial beetroot productivity (Fig. 5D).

\section{Dry mass of beetroots}

For all periods of soil incorporation, the increase in the supply of the green manure increased the dry mass yield of beetroots, with maximum values of 7.73 (fall) and $4.15 \mathrm{Mg}$ $\mathrm{ha}^{-1}$ (spring-summer) with the amount of $15.6 \mathrm{Mg} \mathrm{ha}^{-1}$ of $C$. procera deposited on the soil on the same day as planting (Fig. 6A and 6B). In the reverse breakdown of the interaction, it was observed that treatment related to fertilization with $15.6 \mathrm{Mg} \mathrm{ha}^{-1}$ of $C$. procera, associated with the incorporation time of 0 DBS, allowed the beetroot to achieve averages of 7.77 (fall) and 4.13 (spring-summer) (Fig. 6C and 6D). 
Table 1. Plant height, number of leaves per plant, and diameter of beetroots in two growing seasons (fall and spring-summer) and different amounts of Calotropis procera biomass.

\begin{tabular}{|c|c|c|c|c|}
\hline \multirow[t]{2}{*}{ Growing seasons } & \multicolumn{4}{|c|}{ Amounts of Calotropis procera $\left(\mathrm{Mg} \mathrm{ha}^{-1}\right)$} \\
\hline & 5.4 & 8.8 & 12.2 & 15.6 \\
\hline & \multicolumn{4}{|c|}{ Plant height $(\mathrm{cm})$} \\
\hline Fall & $22.44 \mathrm{a}^{1}$ & $24.03 \mathrm{a}$ & $26.18 \mathrm{a}$ & $26.42 \mathrm{a}$ \\
\hline \multirow[t]{2}{*}{ Spring-summer } & $21.39 \mathrm{~b}$ & $23.18 \mathrm{~b}$ & $23.57 \mathrm{~b}$ & $24.14 b$ \\
\hline & \multicolumn{4}{|c|}{ Number of leaves per plant } \\
\hline Fall & $10.24 \mathrm{a}$ & $11.23 \mathrm{a}$ & $11.40 \mathrm{a}$ & $11.91 \mathrm{a}$ \\
\hline \multirow[t]{2}{*}{ Spring-summer } & $9.22 \mathrm{~b}$ & $9.40 \mathrm{~b}$ & $9.70 \mathrm{~b}$ & $9.87 \mathrm{~b}$ \\
\hline & \multicolumn{4}{|c|}{ Root diameter $(\mathrm{cm})$} \\
\hline Fall & $8.01 \mathrm{a}$ & $8.22 \mathrm{a}$ & $8.39 \mathrm{a}$ & $8.68 \mathrm{a}$ \\
\hline Spring-summer & $5.80 \mathrm{~b}$ & $6.36 \mathrm{~b}$ & $7.35 \mathrm{~b}$ & $8.46 \mathrm{a}$ \\
\hline
\end{tabular}

${ }^{\mathrm{T}}$ Means followed by the same letter in the column do not differ by the Tukey test at $5 \%$ probability.

A

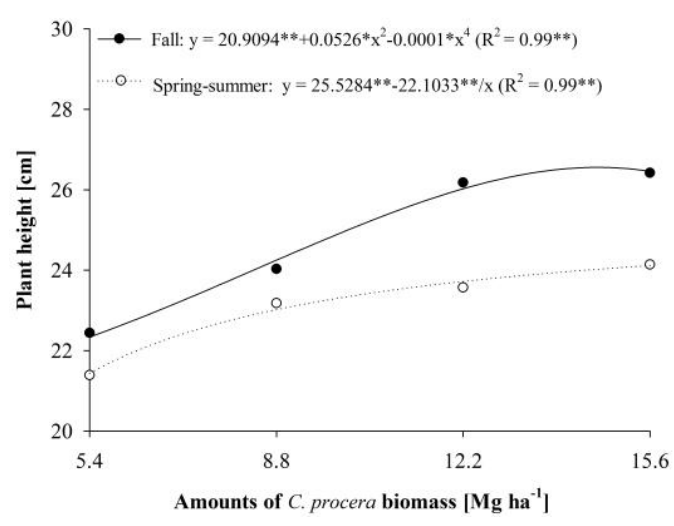

B

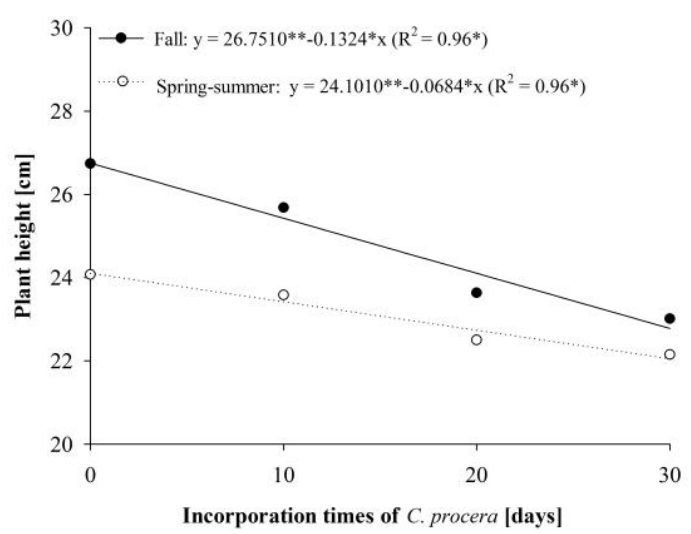

Fig 1. Height of beetroot plants in different amounts of Calotropis procera biomass (A) and incorporation times into the ground (B) in two growing seasons (fall and spring-summer).

Table 2. Plant height, number of leaves per plant, and diameter of beetroots in two growing seasons (fall and spring-summer) and different incorporation times of Calotropis procera into the soil.

\begin{tabular}{|c|c|c|c|c|}
\hline \multirow[t]{2}{*}{ Growing seasons } & \multicolumn{4}{|c|}{ Incorporation times of Calotropis procera (days) } \\
\hline & 0 & 10 & 20 & 30 \\
\hline & \multicolumn{4}{|c|}{ Plant height $(\mathrm{cm})$} \\
\hline Fall & $26.74 \mathrm{a}^{1}$ & $25.68 \mathrm{a}$ & $23.63 \mathrm{a}$ & $23.01 \mathrm{a}$ \\
\hline \multirow[t]{2}{*}{ Spring-summer } & $24.07 \mathrm{~b}$ & $23.57 \mathrm{~b}$ & $22.49 \mathrm{~b}$ & $22.15 \mathrm{~b}$ \\
\hline & \multicolumn{4}{|c|}{ Number of leaves per plant } \\
\hline Fall & $12.04 \mathrm{a}$ & $11.41 \mathrm{a}$ & $10.92 \mathrm{a}$ & $10.39 \mathrm{a}$ \\
\hline \multirow[t]{2}{*}{ Spring-summer } & $10.11 \mathrm{~b}$ & $9.50 \mathrm{~b}$ & $9.41 \mathrm{~b}$ & $9.17 \mathrm{~b}$ \\
\hline & \multicolumn{4}{|c|}{ Root diameter $(\mathrm{cm})$} \\
\hline Fall & $8.68 \mathrm{a}$ & $8.52 \mathrm{a}$ & $8.09 \mathrm{a}$ & $8.01 \mathrm{a}$ \\
\hline Spring-summer & $8.12 \mathrm{~b}$ & $7.16 \mathrm{~b}$ & $6.62 \mathrm{~b}$ & $6.07 \mathrm{~b}$ \\
\hline
\end{tabular}

${ }^{1}$ Means followed by the same letter in the column do not differ by the Tukey test at $5 \%$ probability.
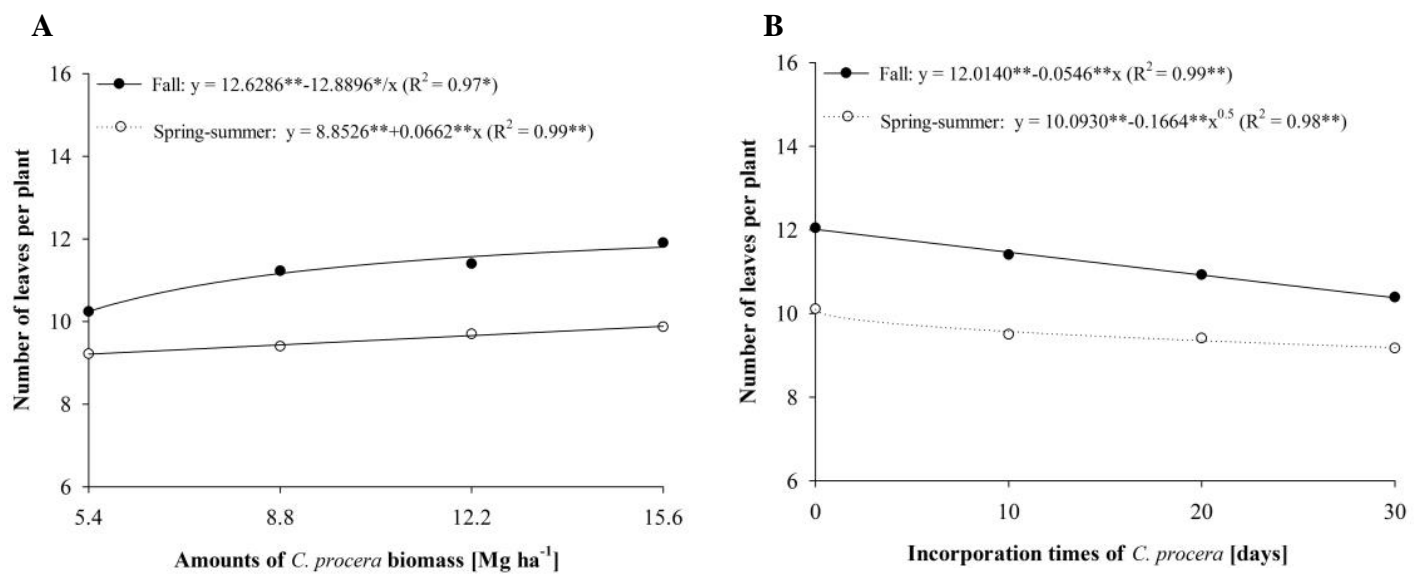

Fig 2. Number of leaves per plant of beetroot in different amounts of Calotropis procera biomass (A) and the incorporation times into the ground (B) in two growing seasons (fall and spring-summer). 

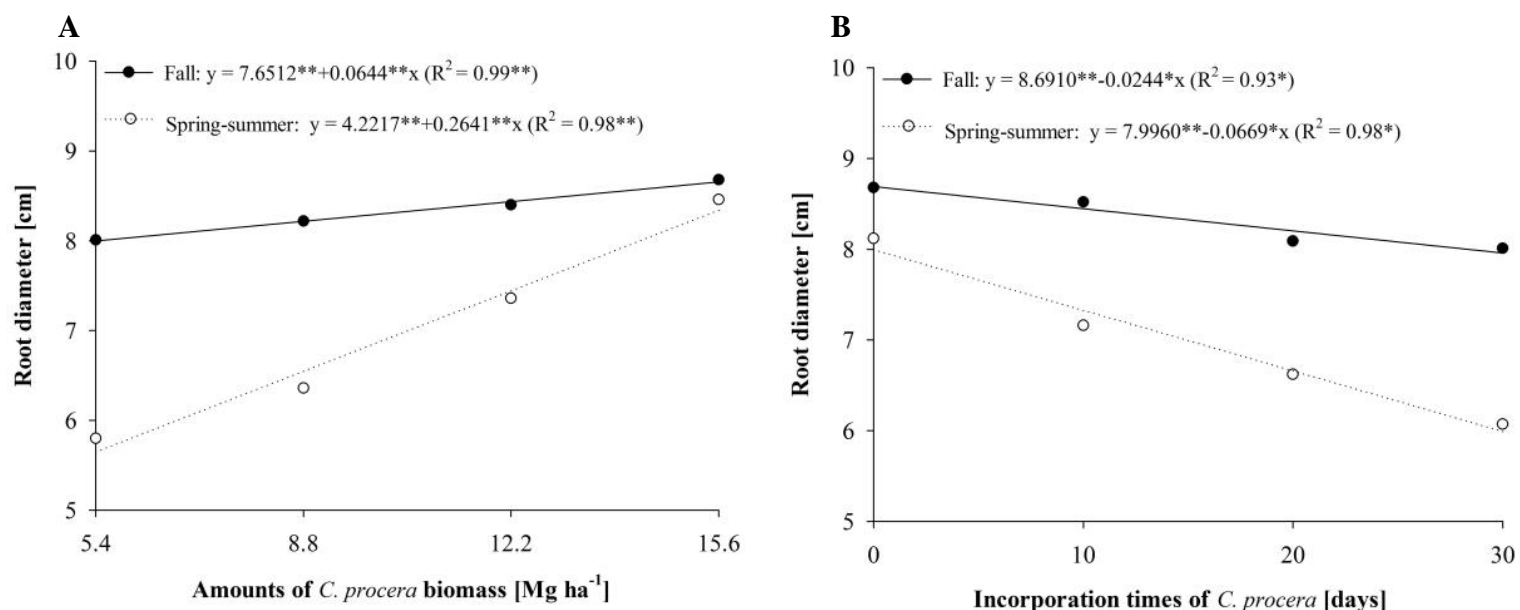

Fig 3. Diameter of beetroots in different amounts of Calotropis procera biomass (A) and the incorporation times into the ground (B) in two growing seasons (fall and spring-summer).

A

Fall

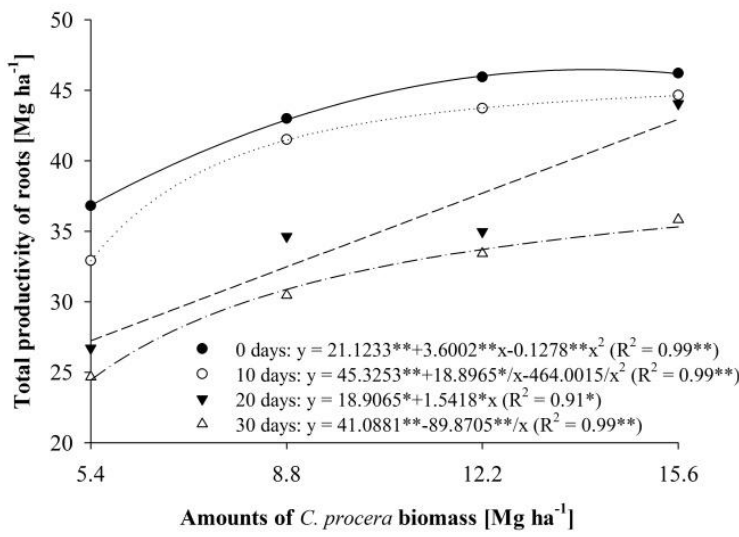

C

Fal

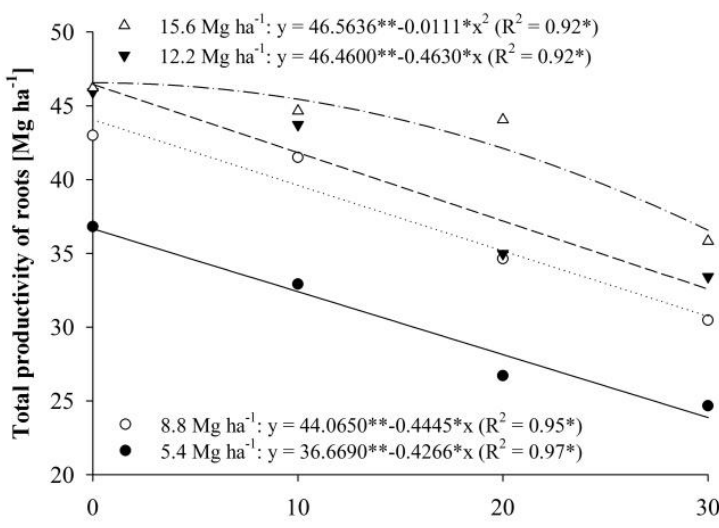

Incorporation times of $C$. procera [days]
Spring-summer

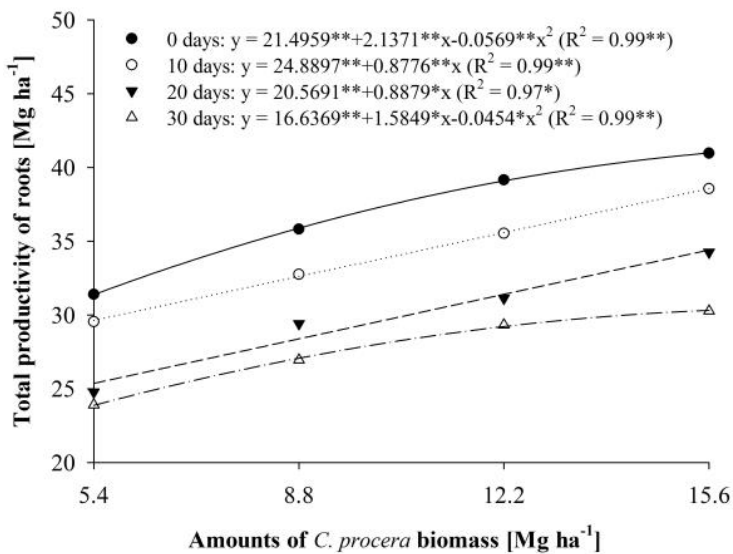

D

Spring-summer

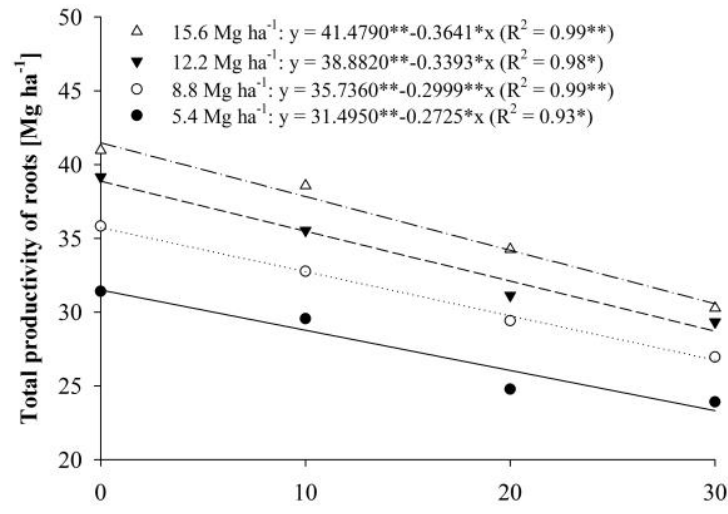

Incorporation times of $C$. procera [days]

Fig 4. Total productivity of beetroots in different amounts of Calotropis procera biomass and incorporation times into the land of the green manure (A. fall; B. spring-summer) and of the converse (C. fall; D. spring-summer) within each growing season. 
A

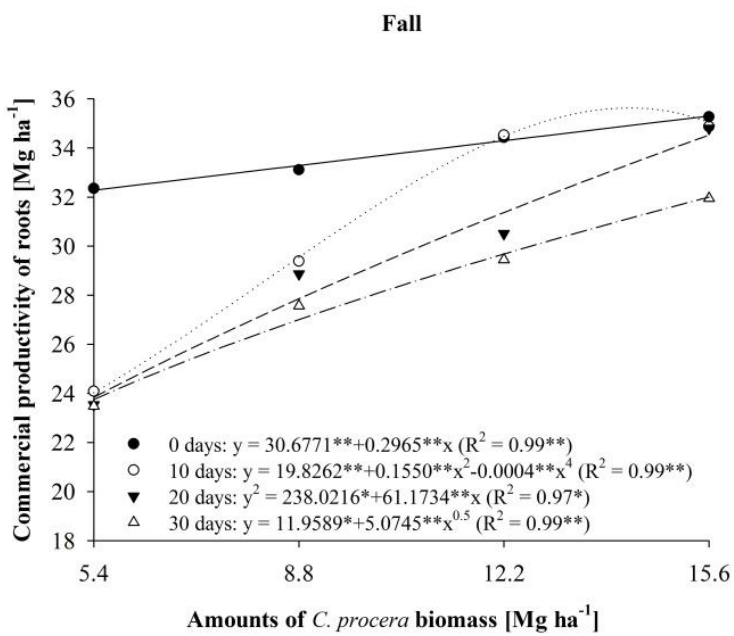

C

Fall

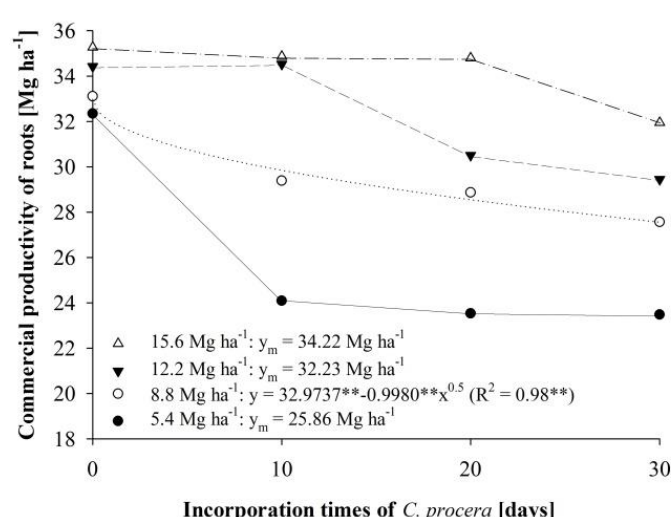

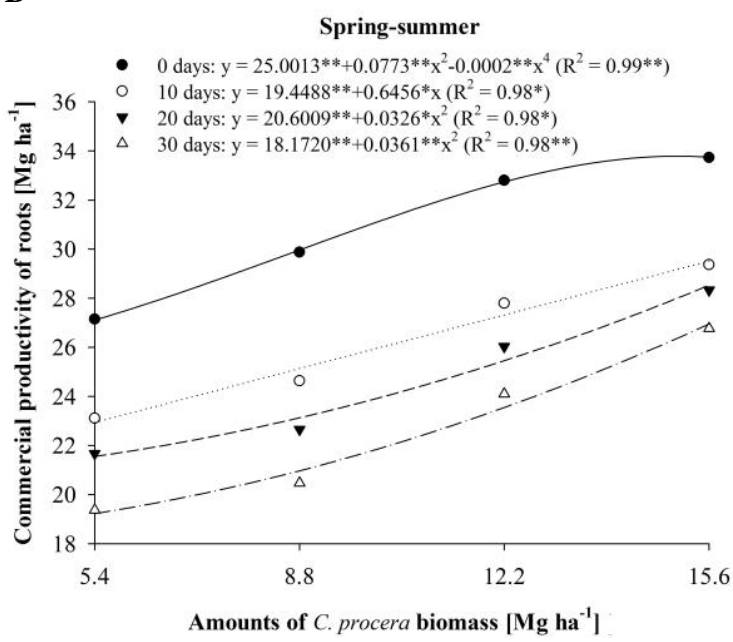

D

Spring-summer

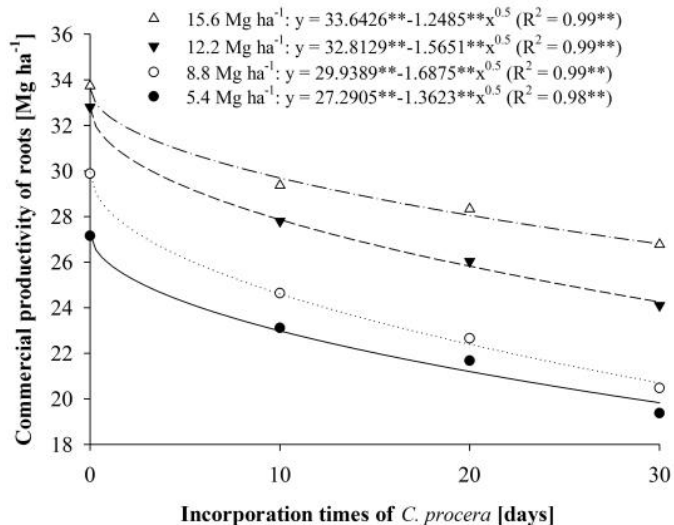

Fig 5. Commercial productivity of beetroots in different amounts of Calotropis procera biomass and incorporation times into the land of green manure (A. fall; B. spring-summer) and the converse (C. fall; D. spring-summer) within each growing season.

A

Fall

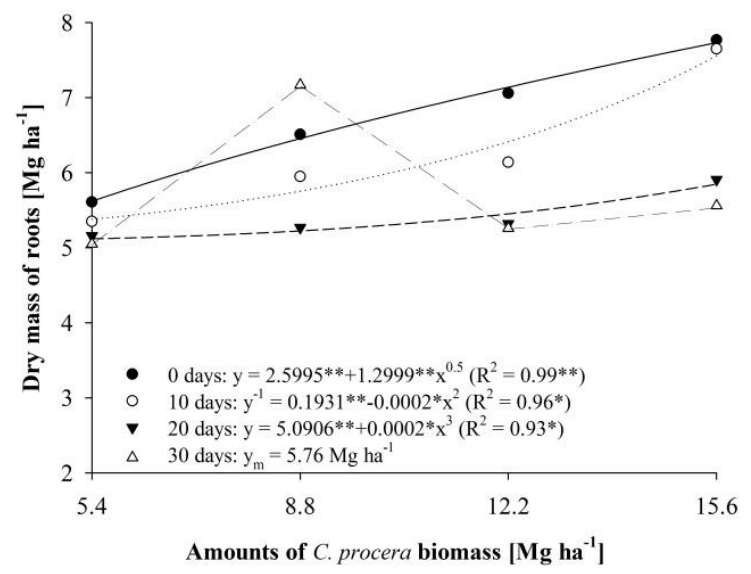

B

Spring-summer

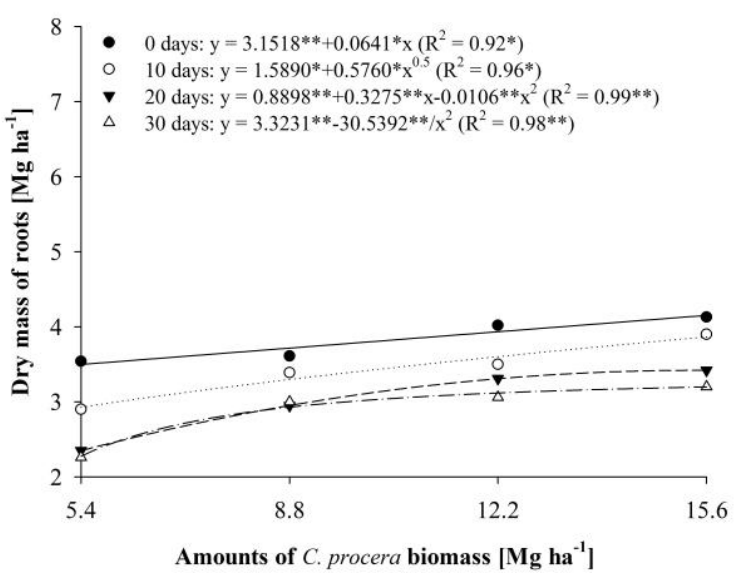


C

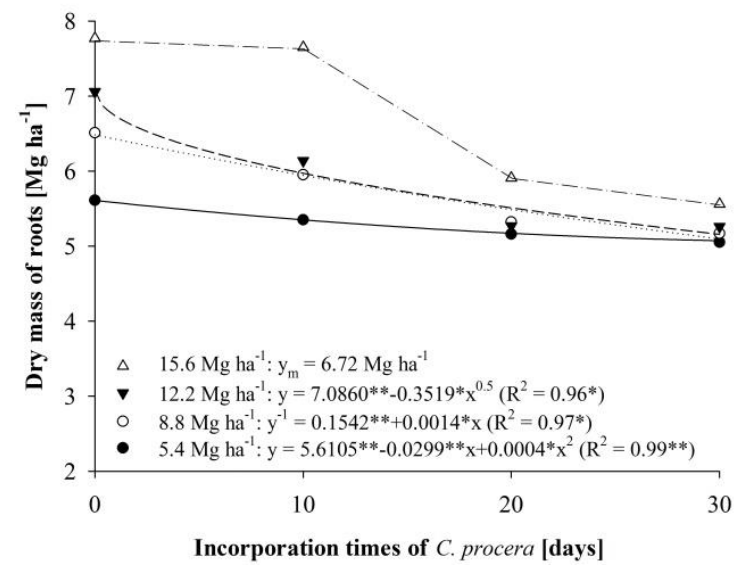

D

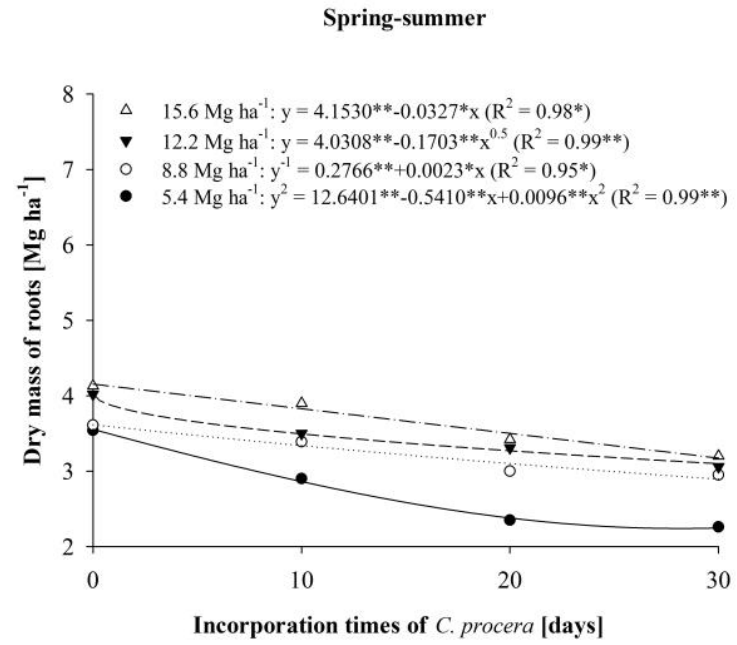

Fig 6. Dry mass of beetroots in different amounts of Calotropis procera biomass and incorporation times into the land of the green manure (A. fall; B. spring-summer) and of the converse (C. fall; D. spring-summer) within each growing season.

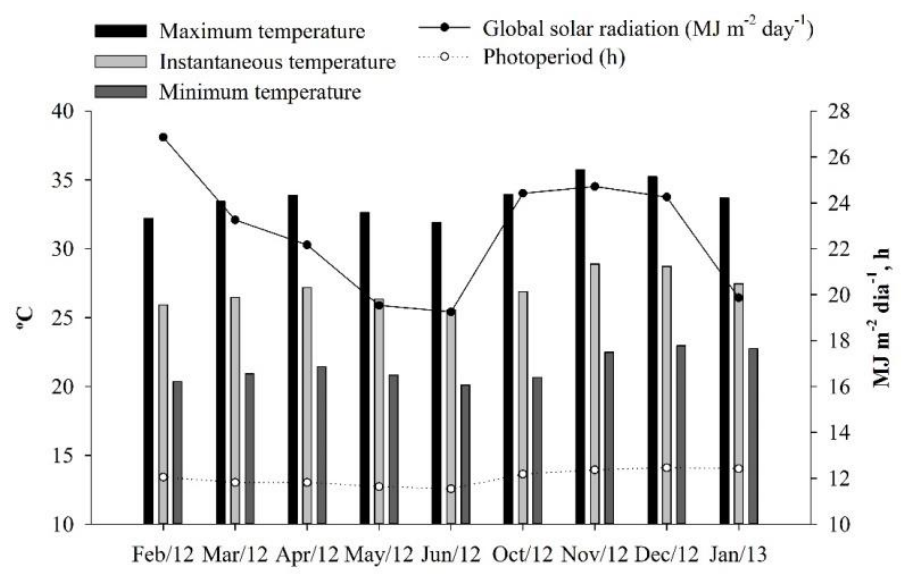

Fig 7. Average values of instantaneous temperatures $\left({ }^{\circ} \mathrm{C}\right)$, maximum and minimum solar radiation $\left(\mathrm{MJ} \mathrm{m}^{-2}\right.$ day $\left.^{-1}\right)$, and photoperiod (h) in each of the beetroot growing season (2012-2013).

\section{Discussion}

\section{Effect of the C. procera biomass amounts}

In both growing seasons (fall and spring-summer), plant height, number of leaves per plant, diameter, total and commercial productivity, and dry mass of roots showed increasing responses with the increased amount of $C$. procera provided to the culture via green manure. These positive results are probably due to the higher availability of macro $(\mathrm{N}, \mathrm{P}, \mathrm{K}, \mathrm{Ca}$, and $\mathrm{Mg}$ ) and micro-nutrients $(\mathrm{B}, \mathrm{Cu}, \mathrm{Fe}, \mathrm{Mn}$, $\mathrm{Zn}$, and $\mathrm{Na}$ ) in the soil, which, when released by $C$. procera, can promote the improvement or maintenance of soil fertility. Alves et al. (2008) emphasize that the omission of macronutrients, particularly $\mathrm{N}, \mathrm{P}, \mathrm{K}$, and $\mathrm{Ca}$, caused losses in the development of the beetroot, decreasing height, number of leaves, and dry weight (shoot and roots) and affecting the nutrition of vegetable crop, which was reflected in morphological changes.

In addition to the mineralization of the constituents of $C$. procera biomass, the fertilization with plant species that occur spontaneously in the semiarid region also favors the microbiological aspects of soil, with an increase in the number of actinomycetes, fungi, and beneficial bacteria to plant growth since they operate in the solubilization of nutrients of the green manure (Batista et al., 2013). The constant irrigation and occurrence of medium temperatures above $26{ }^{\circ} \mathrm{C}$ during the experiments (Fig. 7) may have been stimulant conditions for this microbial activity.

A study in semiarid Potiguar (Mossoró-RN) demonstrated that the best productive performance of the beetroot was obtained when fertilized with $C$. procera in the amount of $21.0 \mathrm{Mg} \mathrm{ha}^{-1}$, achieving total and marketable root productivity $18.74 \mathrm{Mg} \mathrm{ha}^{-1}$ and $16.33 \mathrm{Mg} \mathrm{ha}^{-1}$, respectively (Batista et al., 2016). In the same city as the previous study, Silva et al. (2011) found that beetroot fertilized with $15.6 \mathrm{Mg}$ $\mathrm{ha}^{-1}$ of hairy woodrose biomass reached commercial root productivity of $9.60 \mathrm{Mg} \mathrm{ha}^{-1}$ and a dry mass yield of $2.14 \mathrm{Mg}$ $\mathrm{ha}^{-1}$, thus strengthening the potential of the C. procera as an alternative to green manuring with spontaneous species of Caatinga. 


\section{Effect of the incorporation times of C. procera}

The study of the incorporation time of $C$. procera into the soil allowed us to identify the moment of synchronization between the mineralization of the vegetable residue and the period of maximum nutritional requirements of beetroot (Myers et al., 1994); i.e., the green manure, when incorporated to the soil on the planting day of the crop, had the perfect time to make available in the soil solution the nutrients present in its chemical composition.

The higher demand of nutrients by beetroot takes place in the period 50 to 60 days after sowing for nitrogen, 30 to 50 days for phosphorus, and 30 to 40 days for potassium (Grangeiro et al., 2007), so about 45 days total of incubation of the green manure are needed for greater productivity for this vegetable crop. It is important to note that this recommended time did not change between growing seasons, perhaps because the variation in temperature and in solar radiation (Fig. 7) was unable to promote changes in the speed of the reactions between the microbiota and soil organic matter. Torres et al. (2005) found that most mineralization of $\mathrm{N}$ in crops used as green manures occurred in the first 42 days after being desiccated, relating it to the low $\mathrm{C} / \mathrm{N}$ ratio of the plant material (20-25/1). A similar proportion was also observed in the chemical composition of the $C$. procera $(25 / 1)$.

Corroborating this result, Silva et al. (2011) obtained the maximum productivity of beetroots when they were fertilized with hairy woodrose on the sowing day of the crop. This green manure, as well as the $C$. procera, had carbon/nitrogen ratio of $25 / 1$.

\section{Effect of growing seasons}

To assess the influence of climatic conditions on the growth and development of vegetable crops, experiments must be conducted in different growing seasons, that is, from a different approach from previous studies conducted in individual situations or under controlled conditions (Kenter et al., 2006). This influence was observed in different cultural cycles of beetroots in the fall (85 days) and spring-summer (80 DBS), as well as in the higher agronomic yield obtained in the first growing season. Probably, average temperatures close to $26{ }^{\circ} \mathrm{C}$ and a reduced photoperiod (under $12 \mathrm{~h}$ ) favored vegetative growth and the accumulation of photoassimilates in the culture roots in the fall (Fig. 7).

Moreover, the high temperatures, higher radiation, and prolonged photoperiod in the spring-summer (Fig. 7) may have contributed to a reduction in the accumulation of biomass by the roots of the beet; this condition has a direct influence on the development of species, causing a decrease in the growth cycle of the culture (Taiz and Zeiger, 2013; Barlog et al., 2013; Kenter et al., 2006). High temperatures can also decrease the dry mass accumulation in $\mathrm{C} 3$ species because of increasing photorespiration (Polley, 2002).

Similarly, Souza et al. (2016) observed that the green mass yield of arugula fertilized with $C$. procera was higher in the fall compared to the spring-summer cropping. Silva et al. (2017), studying fertilization with $C$. procera in radish culture, also obtained maximum productivity of commercial roots in the fall-winter compared to spring-summer planting. According to Fontanétti et al. (2004), the green manuring reduces the thermal and water variations in the surface layer of the soil and provide the formation and stabilization of aggregates, with improvement in aeration conditions, infiltration, and moisture retention in the soil.

\section{Materials and Methods}

\section{Study site}

The experiments were conducted in Serra Talhada-PE ( $7^{\circ} 57^{\prime} 15^{\prime \prime}$ south latitude, $38^{\circ} 17^{\prime} 41^{\prime \prime}$ west longitude, and altitude of $461 \mathrm{~m}$ ) in two growing seasons: fall (March 27 to June 20, 2012) and spring-summer (October 31 to January 19, 2013). The local climate, according to Köppen, is Bwh, called semiarid, warm, and dry, with summer rains, a thermal annual average of $24.7{ }^{\circ} \mathrm{C}$, and average annual rainfall of $642.10 \mathrm{~mm}$ (SUDENE, 1990; Medeiros et al., 2005). The average meteorological data from the conducting period of the experiments are shown in Fig. 7.

Experiments were carried out in soil with a sandy loam texture. Chemical characteristics at a depth of $0-0.20 \mathrm{~m}$ before installing the experiments were, in the fall, $\mathrm{pH}=7.2 ; \mathrm{P}$ $=14.0 \mathrm{mg} \mathrm{dm}{ }^{-3} ; \mathrm{K}^{+}=0.6 \mathrm{cmol}_{\mathrm{c}} \mathrm{dm}^{-3} ; \mathrm{Al}^{3+}=0.0 \mathrm{cmol}_{\mathrm{c}} \mathrm{dm}^{-3}$; $\mathrm{Ca}^{2+}=3.9 \mathrm{cmol}_{\mathrm{c}} \mathrm{dm}^{-3} ; \mathrm{Mg}^{2+}=1.2 \mathrm{cmol}_{\mathrm{c}} \mathrm{dm}^{-3}$; total porosity $47.6 \%$; density $1.3 \mathrm{~g} \mathrm{~cm}^{-1}$; clay $=11.6 \%$; sand $=78.36 \%$; and organic matter content of $12.8 \mathrm{~g} \mathrm{~kg}^{-1}$ and, in the springsummer, $\mathrm{pH}=6.6 ; \mathrm{P}=150.0 \mathrm{mg} \mathrm{dm}{ }^{-3} ; \mathrm{K}^{+}=0.7 \mathrm{cmol}_{\mathrm{c}} \mathrm{dm}^{-3}$; $\mathrm{Al}^{3+}=0.0 \mathrm{cmol}_{\mathrm{c}} \mathrm{dm}^{-3} ; \mathrm{Ca}^{2+}=3.4 \mathrm{cmol}_{\mathrm{c}} \mathrm{dm}^{-3} ; \mathrm{Mg}^{2+}=2.0$ $\mathrm{cmol}_{\mathrm{c}} \mathrm{dm}^{-3}$; total porosity $47.6 \%$; density $1.3 \mathrm{~g} \mathrm{~cm}^{-1}$; clay $=$ $11.6 \%$; sand $=78.4 \%$; and organic matter content of $8.4 \mathrm{~g} \mathrm{~kg}$ 1

\section{Experimental design, treatments, and plant material}

The experimental design was a randomized complete block with three replications. The treatments were arranged in a factorial $4 \times 4$, with the first factor consisting of four amounts of $C$. procera biomass $\left(5.4,8.8,12.2\right.$, and $15.6 \mathrm{Mg} \mathrm{ha}^{-1}$ on a dry basis) and the second factor being four times of biomass incorporation into the soil $(0,10,20$, and 30 DBS $)$. The biomass amounts of $C$. procera were based on those used by Silva et al. (2011) in the production of beetroot fertilized with $M$. aegyptia in semiarid conditions.

Each experimental unit had total area of $1.44 \mathrm{~m}^{2}$, with a harvest plot of $0.80 \mathrm{~m}^{2}$. The beetroot cultivar used was 'Early Wonder', recommended for the semiarid conditions of northeast Brazil.

\section{Conduction of experiments and use of C. procera}

The soil preparation consisted of manual cleaning of the experimental area with the aid of a hoe, followed by harrowing and the construction of the beds. Six planting rows were arranged transversely in each plot, spaced at $0.20 \mathrm{~m} \mathrm{x}$ $0.10 \mathrm{~m}$.

The $C$. procera biomass was collected next to the experiment site and then crushed in a conventional forage machine to yield fragments of two or three centimeters that were dried until hay conditions arose (10\% humidity). From samples of this material was determined the nutrient content in the dry matter: $\mathrm{N}=17.4 \mathrm{~g} \mathrm{~kg}^{-1} ; \mathrm{P}=4.4 \mathrm{~g} \mathrm{~kg}^{-1} ; \mathrm{K}=23.5 \mathrm{~g}$ $\mathrm{kg}^{-1} ; \mathrm{Ca}=14.3 \mathrm{~g} \mathrm{~kg}^{-1} ; \mathrm{Mg}=23.0 \mathrm{~g} \mathrm{~kg}^{-1} ; \mathrm{Fe}=463.0 \mathrm{mg} \mathrm{kg}^{-1}$, $\mathrm{Zn}=40.0 \mathrm{mg} \mathrm{kg}^{-1} ; \mathrm{Cu}=29.0 \mathrm{mg} \mathrm{kg}^{-1} ; \mathrm{Mn}=90.0 \mathrm{mg} \mathrm{kg}^{-1} ; \mathrm{B}$ $=71.0 \mathrm{mg} \mathrm{kg}^{-1} ; \mathrm{Na}=1,640.0 \mathrm{mg} \mathrm{kg}^{-1}$, M.O. $=764.0 \mathrm{mg} \mathrm{kg}^{-1}$; and $\mathrm{C} / \mathrm{N}=25 / 1$.

The manure was incorporated in the layer of $0-0.20 \mathrm{~m}$ soil in the experimental plots, according to the treatments. Daily irrigations (micro-sprinkler system) were carried out in two shifts to promote the microbial activity of the soil in the mineralization process of organic matter.

Direct seeding was conducted two centimeters deep, seeding three seedlings per hill. After ten days of emergence, 
thinning occurred, leaving one plant per hole. Hand weedings were carried out whenever necessary.

\section{Growing seasons}

Planting of beetroot in the first growing season (fall) was done on March 27, 2012, while the spring-summer planting was held on October 31,2012. The beetroot harvest in the fall was performed 85 days after sowing, while in the springsummer, it was done after 80 days.

\section{Measured characteristics}

At the time of harvest, the following characteristics were evaluated: plant height $(\mathrm{cm})$, obtained by using a ruler to measure a sample of twenty plants from the ground level to the tip of the highest leaf; number of leaves per plant, determined in a sample of twenty plants by directly counting the number of leaves larger than three centimeters in length, starting from the basal leaves until the last open sheet; root diameter $(\mathrm{cm})$, determined in the same sample of twenty plants using a digital caliper; total root yield $\left(\mathrm{Mg} \mathrm{ha}^{-1}\right)$, determined from the fresh weight of all roots of the useful area; and the commercial productivity of roots $\left(\mathrm{Mg} \mathrm{ha}^{-1}\right)$, determined from the fresh mass of plant roots of the harvest area free of cracks, bifurcations, nematodes, and mechanical damage; and dry mass of roots $\left(\mathrm{Mg} \mathrm{ha}^{-1}\right)$, estimated from the weight of the mass of twenty plants of the harvest area after drying in an oven with forced air, with the temperature set at $65^{\circ} \mathrm{C}$, until constant mass was achieved.

\section{Statistical analysis}

Data were subjected to analysis of variance by the $\mathrm{F}$ test at $5 \%$ probability. The comparison of the two experiments was conducted using a joint analysis with the aid of the SISVAR software (Ferreira, 2011). A response curve fitting procedure was done between assessed traits and quantitative factors through the SigmaPlot 12.0 software (Systat Software, 2011). The Tukey test $(\mathrm{p}<0.05)$ was used to compare means between growing seasons.

\section{Conclusion}

From the results of this work, it can be seen that the agronomic performance of the beetroot is subject to variations according to the amount and incorporation time of the green biomass of $C$. procera. The growing season also affected the culture performance, possibly by the influence of climate variations. The best agronomic performance of the beetroot was obtained by fertilization with $15.6 \mathrm{Mg} \mathrm{ha}^{-1} C$. procera. The ideal time of incorporation of green manure coincided with the date of the sowing of beetroot. Cultivation in the fall resulted in higher total and commercial productivity of the roots of beetroot fertilized with $C$. procera.

\section{Acknowledgements}

Support Foundation for Science and Technology of the State of Pernambuco (FACEPE) by funding of the research project.

\section{References}

Alcântara FA, Ferreira Neto AE, Paula MB, Mesquita HA, Muniz JA (2000) Adubação verde na recuperação da fertilidade de um Latossolo vermelho-escuro degradado. Pesqui Agropecu Bras. 35:277-288.

Alves AU, Prado RM, Gondim ARO, Fonseca IM, Cecílio Filho AB (2008) Desenvolvimento e estado nutricional da beterraba em função da omissão de nutrientes. Hortic Bras. 26:292-295.

Andrade MVM, Silva DS, Andrade AP, Medeiros NA, Pimenta Filho EC, Cândido MJD, Pinto MSC (2008) Produtividade e qualidade da flor-de-seda em diferentes densidades e sistemas de plantio. Rev Bras Zootecn. 37:18.

Barlog P, Grzebis W, Peplinski K, Szczepaniak W (2013) Sugar beet response to balanced nitrogen fertilization with phosphorus and potassium. Part I. Dynamics of beet yield development. Bulg J Agric Sci. 19:1311-1318.

Batista MAV, Bezerra Neto F, Ambrosio MMQ, Guimarães LMS, Saraiva JPB, Silva ML (2013) Atributos microbiológicos do solo e produtividade de rabanete influenciados pelo uso de espécies espontâneas. Hortic Bras. 31:587-594.

Batista MAV, Bezerra Neto F, Silva ML, Ambrósio MMQ, Cunha JLXL (2016) Atributos de solo-planta e de produção de beterraba influenciados pela adubação com espécies da Caatinga. Hortic Bras. 34:31-38.

Bezerra Neto F, Góes SB, Sá JR, Linhares PCF, Góes GB, Moreira JN (2011) Desempenho agronômico da alface em diferentes quantidades e tempos de decomposição de jitirana verde. Rev Bras Cienc Agrar. 6:236-242.

Bezerra Neto F, Oliveira LJ, Santos AP, Lima JSS, Silva IN (2014) Otimização agroeconômica da cenoura fertilizada com diferentes doses de jitirana. Rev Cienc Agron. 45:305311.

Carvalho Júnior SB, Furtado DA, Silva VR, Dantas RT, Lima ISP, Lima VLA (2010) Produção e avaliação bromatológica de espécies forrageiras irrigadas com água salina. Rev Bras Eng Agric Ambient. 14:1045-1051.

Crews TE, Peoples MB (2005) Can the synchrony of nitrogen supply and crop demand be improved in legume and fertilizer-based agroecosystems? A review. Nutr Cycl Agroecosys. 72:101-120.

Ferreira DF (2011) Sisvar: a computer statistical analysis system. Cienc Agrotec. 35:1039-1042.

Filgueira FAR (2008) Novo manual de olericultura: agrotecnologia moderna na produção e comercialização de hortaliças, 3rd edn. UFV, Viçosa. 421 p.

Fontanétti A, Carvalho GJ, Morais AR, Almeida K, Duarte WF (2004) Adubação verde no controle de plantas invasoras nas culturas de alface americana e de repolho. Cienc Agrotec. 28:967-973.

Góes SB, Bezerra Neto F, Linhares PCF, Góes, GB, Moreira JN (2011) Productive performance of lettuce at different amounts and times of decomposition of dry scarlet starglory. Rev Cienc Agron. 42:1036-1042.

Grangeiro LC, Negreiros MZ, Souza BS, Azevedo PE, Oliveira SL, Medeiros MA (2007) Acúmulo e exportação de nutrientes em beterraba. Cienc Agrotec. 31:267-273.

Kenter CH, Hoffmann CM, Märländer B (2006) Effects of weather variables on sugar beet yield development (Beta vulgaris L.). Eur J Agron. 24:62-69.

Linhares PCF, Pereira MFS, Assis JP, Bezerra AKH (2012). Quantidades e tempos de decomposição da jitirana no desempenho agronômico do coentro. Cienc Rural. 42:243248.

Linhares PCF, Silva ML, Borgonha W, Maracajá PB, Madalena JAS (2009) Velocidade de decomposição da florde-seda no desempenho agronômico da rúcula cv. Cultivada. Rev Verde. 4:46-50. 
Medeiros SS, Cecílio RA, Melo Júnior JCF, Silva Júnior JLC (2005) Estimativa e espacialização das temperaturas do ar mínimas, médias e máximas na região Nordeste do Brasil. Rev Bras Eng Agric Ambient. 9:247-255.

Myers RJK, Palm CA, Cuevas E, Gunatilleke IUN, Brossard M (1994) The synchronization of nutrient mineralization and plant nutrient demand. In: Woomer PL, Swift MJ (eds.) The biological management of tropical soil fertility. John Wiley and Sons, New York. p. 81-116.

Oliveira MKT, Bezerra Neto F, Barros Júnior AP, Lima JSS, Moreira JN (2011) Desempenho agronômico da cenoura adubada com jitirana antes de sua semeadura. Rev Cienc Agron. 42:364-372.

Polley HW (2002) Implications of atmospheric and climatic change for crop yield and water use efficiency. Crop Sci. 42:131-140.

Sediyama MAN, Santos IC, Lima PC (2014) Cultivo de hortaliças no sistema orgânico. Rev Ceres. 61:829-837.

Silva AFA, Souza ÊGF, Barros Júnior AP, Bezerra Neto F, Silveira LM (2017) Desempenho agronômico do rabanete adubado com Calotropis procera (Ait.) R. Br. em duas épocas de cultivo. Rev Cienc Agron. 48:328-336.

Silva ML, Bezerra Neto F, Linhares PCF, Bezerra AKH (2013) Produção de cenoura fertilizada com flor-de-seda (Calotropis procera (Ait.) R. Br.). Rev Cienc Agron. 44:732-740.

Silva ML, Bezerra Neto F, Linhares PCF, Sá JR, Lima JSS, Barros Júnior AP (2011) Produção de beterraba fertilizada com jitirana em diferentes doses e tempos de incorporação ao solo. Rev Bras Eng Agric Ambient. 15:801-809.
Souto PC, Sales FCV, JS, Santos RV, Souza AA (2008) Biometria de frutos e número de sementes de Calotropis procera (Ait.) R. Br. no semi-árido da Paraíba. Rev Verde. 3:108-113

Souza ÊGF, Lima EF, Barros Júnior AP, Silveira LM, Bezerra Neto F, Cruz EA (2017) Production of lettuce under green manuring with Calotropis procera in two cultivation seasons. Rev Caatinga. 30:391-400.

Souza ÊGF, Santana FMS, Martins BNM, Santos MG, Cerqueira Júnior EP, Barros Júnior AP, Silveira LM, Bezerra Neto F, Lins HA, Albuquerque JRT (2016) Agronomic response of arugula to green fertilization with rooster tree during two culture times. Afr J Agric Res. 11:4931-4938.

Superintendência do Desenvolvimento do Nordeste SUDENE (1990) Dados pluviométricos mensais do Nordeste: Estado de Pernambuco. Grafset, Recife. 363 p.

Systat Software (2011) Sigmaplot for windows: version 12.0. Systat Software Inc., San Jose.

Taiz L, Zeiger E (2013) Fisiologia vegetal, 5rd edn. ArtMed, Porto Alegre. 918 p.

Torres JLR, Pereira MG, Andrioli I; Polidoro J, Fabian AJ (2005) Decomposição e liberação de nitrogênio de resíduos culturais de plantas de cobertura em um solo de cerrado. Rev Bras Cienc Solo. 29:609-618.

Xu X, Hirata E (2005) Decomposition patterns of leaf litter of seven common canopy species in a subtropical Forest: N and P dynamics. Plant Soil. 273:279-289. 